\title{
Historical Mercury Releases from Commercial Products: Global Environmental Implications
}

\section{Citation}

Horowitz, Hannah M., Daniel J. Jacob, Helen M. Amos, David G. Streets, and Elsie M. Sunderland. 2014. "Historical Mercury Releases from Commercial Products: Global Environmental Implications." Environ. Sci. Technol. 48 (17) (September 2): 10242-10250. doi:10.1021/es501337j.

\section{Published Version}

doi:10.1021/es501337j

\section{Permanent link}

http://nrs.harvard.edu/urn-3:HUL.InstRepos:34306003

\section{Terms of Use}

This article was downloaded from Harvard University's DASH repository, and is made available under the terms and conditions applicable to Open Access Policy Articles, as set forth at http:// nrs.harvard.edu/urn-3:HUL.InstRepos:dash.current.terms-of-use\#OAP

\section{Share Your Story}

The Harvard community has made this article openly available.

Please share how this access benefits you. Submit a story.

\section{Accessibility}


1 Historical mercury releases from commercial products: global environmental implications

2 Hannah M. Horowitz, ${ }^{\dagger} *$ Daniel J. Jacob, ${ }^{\dagger, \dagger}$ Helen M. Amos, ${ }^{\dagger}$ David G. Streets, ${ }^{\S}$ and Elsie M.

3 Sunderland ${ }^{\ddagger, \|}$

4

5 Harvard University, Department of Earth and Planetary Sciences, Cambridge, MA, USA

6 'School of Engineering and Applied Science, Harvard University, Cambridge, MA, USA

$7 \quad{ }^{\S}$ Decision and Information Sciences Division, Argonne National Laboratory, Argonne, IL, 8 USA

9 "Department of Environmental Health, Harvard School of Public Health, Boston, MA, USA Submitted to 


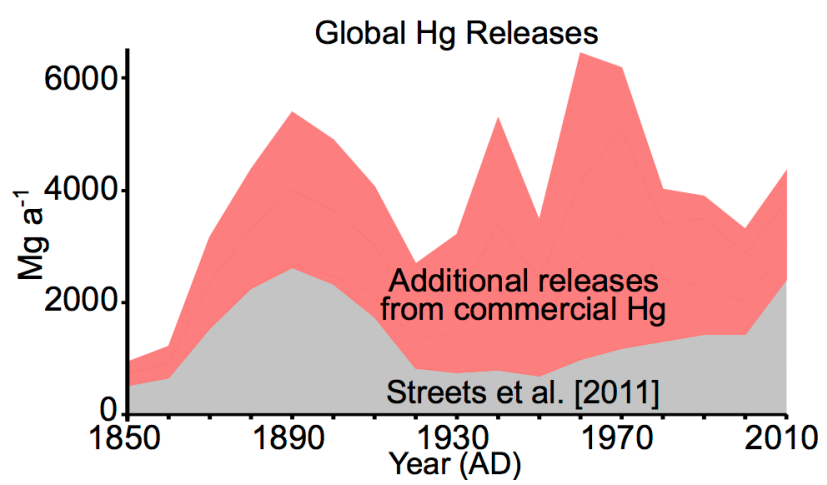

\section{ABSTRACT}

18 Use and disposal of commercial products has contributed a large and previously unquantified

19 anthropogenic source of mercury $(\mathrm{Hg})$ to the global environment over the industrial era, with

20 major implications for $\mathrm{Hg}$ accumulation in environmental reservoirs. We present a global

21 inventory of commercial $\mathrm{Hg}$ uses and releases to the atmosphere, water, soil, and landfills from

221850 to 2010. Previous inventories of anthropogenic $\mathrm{Hg}$ releases have focused almost

23 exclusively on atmospheric emissions. Cumulative anthropogenic $\mathrm{Hg}$ emissions since 1850 have

24 recently been estimated at $220 \mathrm{Gg}$. We find that commercial use of $\mathrm{Hg}$ released an additional 540

25 Gg to the global environment since 1850 (20\% to air, $30 \%$ to water, $30 \%$ to soil, $20 \%$ to

26 landfills). Some of this release has been sequestered in landfills and benthic sediments, but 310

27 Gg actively cycles among geochemical reservoirs and contributes to elevated present-day

28 environmental Hg concentrations. Commercial Hg use peaked in 1970 and has declined sharply

29 since. Using our inventory to force a global biogeochemical model improves model consistency

30 with observed (1) changes in atmospheric deposition recorded in many remote lake sediments

31 and ombrotrophic peat bogs over the industrial era, and (2) declines in atmospheric $\mathrm{Hg}$

32 concentrations since the 1990s.

\section{INTRODUCTION}


Methylmercury, a toxin formed from inorganic $\mathrm{Hg}$, bioaccumulates in aquatic food

35 chains and adversely affects human health on a global scale through fish consumption. ${ }^{1,2} \mathrm{Hg}$ has

36 been mined since antiquity and extensively used in many commercial products, ${ }^{3}$ leading to its

37 eventual release to the environment upon disposal. Hg cycles rapidly between air, water, and soil

38 reservoirs so that releases to any of these reservoirs can contribute to oceanic $\mathrm{Hg}$ levels. ${ }^{4}$

39 Background levels of $\mathrm{Hg}$ in the environment have increased $\sim 3$ fold since pre-industrial times ${ }^{5}$

40 and may be $5-10$ times above natural levels. ${ }^{4,6}$ This has been conventionally attributed to

41 atmospheric emissions from mining and combustion. ${ }^{7,8}$ Here we show that releases of

42 commercial $\mathrm{Hg}$ to air, water, and soil have contributed a large, previously unquantified source of

$43 \mathrm{Hg}$ to the global environment over the industrial era, with major implications for historical and

44 present-day conditions.

$\mathrm{Hg}$ is transferred from its stable lithospheric reservoir to surface environmental reservoirs

46 by natural geological processes, fossil fuel combustion, and mining (including for commercial

47 products). It then is exchanged between the atmosphere, surface ocean, and terrestrial

48 ecosystems on time scales of years to decades. ${ }^{4}$ The atmospheric lifetime of gaseous elemental

$49 \mathrm{Hg}$ is of the order of a year, allowing transport and deposition on a global scale. ${ }^{9} \mathrm{Hg}$ is

50 eventually transferred to long-lived soil and deep-ocean pools over hundreds of years, and

51 returns to the lithosphere to close the cycle on a timescale of thousands of years. ${ }^{10}$ The lasting

52 environmental legacy of $\mathrm{Hg}$ released to surface reservoirs mandates a historical perspective for

53 understanding present-day environmental burdens and for evaluating the effectiveness of

54 regulatory actions such as the Minamata Convention. ${ }^{11}$

While an estimated $215 \mathrm{Gg}$ of $\mathrm{Hg}$ have been emitted directly to the atmosphere since

561850 from fuel combustion, metals smelting, mining, and chlor-alkali plants, an additional 616 
57 Gg have been mined during the same period for numerous commercial uses. ${ }^{12}$ These include

$58 \mathrm{Hg}$-containing products (e.g. batteries) and manufacturing processes that involve $\mathrm{Hg}$ (e.g. vinyl

59 chloride monomer production). Commercial $\mathrm{Hg}$ enters the environment either during use or

60 following product disposal. Previous studies have estimated present-day environmental releases

61 of $\mathrm{Hg}$ from commercial products and processes only for a subset of uses and fate pathways, with

62 a predominant focus on atmospheric emissions. ${ }^{13-23}$ The environmental fate of most of the mined

$63 \mathrm{Hg}$ has not yet been quantified.

64 Commercial $\mathrm{Hg}$ can enter the environment by various pathways. For example, $\mathrm{Hg}$ in

65 paint rapidly volatilizes to the atmosphere. ${ }^{24}$ The chemical manufacturing industry historically

66 discharged large amounts of $\mathrm{Hg}$ directly into waterways, reflected by legacy contamination in

67 many estuaries today. ${ }^{25-28} \mathrm{Hg}$-containing agricultural fungicides and pesticides were applied to

68 soil in large quantities for much of the $20^{\text {th }}$ century. ${ }^{29}$ Discarded Hg-containing batteries have

69 generally been incinerated or landfilled. ${ }^{30,31}$ More recently, many industries have made progress

70 toward recycling $\mathrm{Hg}$ in commercial products or phasing out its use. ${ }^{32}$

Here we quantify the global time-dependent historical releases of commercial $\mathrm{Hg}$ to

72 different environmental reservoirs (air, water, soil, landfills), and include these in a global

73 biogeochemical model ${ }^{4}$ to investigate their impact on historical and present-day global $\mathrm{Hg}$

74 accumulation. Water releases include effluent discharges to both estuaries and inland freshwater

75 systems, and soil releases are deposited to land or vegetation. Previous work has had difficulty

76 reconciling the temporal trend of anthropogenic emissions with archival records of historical

77 atmospheric $\mathrm{Hg}$ deposition, many of which show a peak in the 1970 s. ${ }^{33-36}$ Atmospheric

78 observations indicate a $\sim 20 \%$ to $50 \%$ decrease in total gaseous mercury in the Northern

79 Hemisphere since $1995,{ }^{37,38}$ at odds with atmospheric emission inventories that estimate 
80 increased or flat emissions over this period. ${ }^{12,20}$ Soerensen et al. ${ }^{38}$ suggested that the observed

81 atmospheric trend could be explained by declining oceanic evasion to the atmosphere due to

82 decreased seawater concentrations. Commercial use of Hg peaked in the 1970s and has declined

83 dramatically since, ${ }^{12,39}$ and we investigate how the related changes in historical commercial $\mathrm{Hg}$

84 releases may play a role in reconciling these trends.

\section{METHODS}

We present a global, historical analysis tracking $\mathrm{Hg}$ from when it is mined, through all

87 known intentional uses and fate pathways, to its final time-dependent releases to different

88 environmental reservoirs. Commercial $\mathrm{Hg}$ uses are grouped by similar environmental release

89 patterns for a total of 14 use categories (Table 1). We estimate global environmental releases of

$90 \mathrm{Hg}$ and track recycled and landfilled quantities from each use category on a decadal scale

91 between 1850 and 2010. We first estimate the quantity of $\mathrm{Hg}$ consumed in each use category

92 constrained by the total amount of $\mathrm{Hg}$ mined globally. We then apply a series of distribution

93 factors that vary temporally and by economic development status of different countries to

94 distribute commercial $\mathrm{Hg}$ to its final environmental releases following a simplified substance

95 flow analysis (e.g. Barr Engineering ${ }^{14}$ ). Finally, we investigate the impacts of these global, time-

96 dependent releases on accumulation and cycling among environmental reservoirs using a seven-

97 box biogeochemical $\mathrm{Hg}$ model.

98 Global Commercial Hg Consumption Patterns, 1850 - 2010

99 We assume that significant $\mathrm{Hg}$ release from non-mining commercial $\mathrm{Hg}$ uses began in

100 1850. Anthropogenic releases prior to 1850 were mainly from mining. ${ }^{12}$ Overall decadal

101 estimates of the magnitude of $\mathrm{Hg}$ used throughout the industrial era are constrained by global $\mathrm{Hg}$ 
102 production from mining between 1850 and $1980^{12,39}$ combined with changes in the Hg supply

103 available for consumption due to government stockpiling ${ }^{40}$ (Figure 1). We assume that mined $\mathrm{Hg}$

104 that is not stockpiled is incorporated into products within a decade. Secondary $\mathrm{Hg}$ sources

105 (releases from strategic stockpiles, recovery from mining and smelting, and recycling of $\mathrm{Hg}$ -

106 containing products) became significant after 1980. ${ }^{13,32,41}$ Therefore, for $1990-2010$, we use

107 total $\mathrm{Hg}$ consumption from Wilson et al. ${ }^{20}$ which includes both primary mining and secondary

108 sources.

109 We then partition the global total $\mathrm{Hg}$ supply into individual uses. Methods used to

110 estimate $\mathrm{Hg}$ consumption for each category vary depending on data availability. We divide

111 countries into two groups, developed countries (North America, OECD/EU Europe, Oceania)

112 and developing countries including economies in transition (rest of world), based on similarities

113 in environmental regulations and control technologies within each group that lead to differences

114 in $\mathrm{Hg}$ use and release patterns between them. Data from Streets et al. ${ }^{12}$ are used to constrain total

$115 \mathrm{Hg}$ consumed globally for the chlor-alkali industry between 1850 and 1930 and silver and gold

116 mining between 1850 and 1990, including artisanal and small-scale gold mining (ASGM).

117 Decadal use patterns available for the United States ${ }^{42,43}$ are used to estimate global consumption

118 of $\mathrm{Hg}$ in the remaining uses for 1850 - 1960. During this period, the US consumed $\sim 25 \%$ of total

$119 \mathrm{Hg}$ mined globally and its $\mathrm{Hg}$ use data is the most complete.

120 The ca. 1970 onset of environmental regulations targeting $\mathrm{Hg}$ releases in developed

121 countries resulted in major changes in $\mathrm{Hg}$ consumption patterns. ${ }^{25} \mathrm{We}$ therefore estimate $\mathrm{Hg}$

122 consumption separately for developing countries from 1970 on. For 1970 and 1980, we divide

123 the global total $\mathrm{Hg}$ supply between the developed and developing world by the fraction of global

124 GDP held by each group of countries. ${ }^{44}$ Consumption patterns for the developed world are 
125 assumed to follow those of the US in 1970 and $1980 .{ }^{45}$ Consumption patterns for the developing

126 world in 1970 and 1980 are assumed to be similar to those of the US in 1960, when Hg use was

127 unregulated. For 1990 - 2000, we use regionally resolved Hg consumption data from Wilson et

128 al. ${ }^{20}$ For 2010, we use annual consumption data from AMAP/UNEP ${ }^{22}$ for the uses available, and

129 extrapolate the $2000-2005$ trend from Wilson et al. ${ }^{20}$ for the remaining uses.

130 Environmental Releases of Commercial $\mathrm{Hg}$

131 Figure 2 shows a generic substance flow analysis diagram that tracks the fate of

132 commercial $\mathrm{Hg}$ for each decade and use category (Table 1) to its eventual release in different

133 environmental reservoirs. First, the Hg consumed in each use category is divided among direct

134 releases to air, water, and soil, recycling, and disposal to solid waste or wastewater treatment

135 ('Tier 1' distribution factors). Certain use categories have additional disposal pathways with

136 environmental fates that are distinct from general solid waste or wastewater disposal. $\mathrm{Hg}$

137 entering the three waste disposal pathways is divided further ('Tier 2' distribution factors). Solid

138 waste is split between disposal in landfills, incineration, and direct disposal to soil, wastewater is

139 partially captured in sewage sludge and the rest is released to water, and 'Other Disposal' is

140 distributed between air, land, and landfills. A third tier of distribution factors is needed to

141 characterize environmental releases for solid waste incineration (emitted to air, or captured in ash

142 and then deposited to soil or in landfills) and sewage sludge (incinerated and emitted to air,

143 applied to soil, or disposed of in landfills). Dental amalgam has unique fate pathways not

144 represented in Figure 2. Some $\mathrm{Hg}$ in teeth is permanently stored during burial ${ }^{46}$ or partially

145 released to air, water, and soil upon cremation. 
147 (Tables S1 and S2). Distribution factors are applied globally for 1850 - 1960, and separately for

148 the developed and developing world between 1970 and 2010. We use previous decadal estimates

149 from Streets et al. ${ }^{12}$ for global atmospheric emissions from chlor-alkali plants, silver and large-

150 scale gold mining, and ASGM, except for 2010 ASGM emissions for which we use

151 AMAP/UNEP ${ }^{22}$ estimates.

Temporal variability in distribution factors is governed by the availability of evidence

153 that releases have changed from one decade to another due to regulatory controls and other

154 factors. Global distribution factors are held constant in time through 1950, with variation in 1960

155 for three use categories (VCM and Other Chemical, Paint, and Pesticides and Fertilizer). This

156 reflects significant changes in consumption patterns (a change from chemicals to laboratory uses,

157 marine anti-fouling paint to home interior/exterior latex paint, and agricultural to pulp and paper

158 fungicides, respectively). Different distribution factors in the developed world are applied for

159 each decade between 1970 and 2010. Developing world distribution factors are assumed constant

160 for 1970 - 2010. The "Other" category in Table 1 ( $9 \%$ of $1850-2010$ global consumption)

161 encompasses a diverse set of uses with an unknown distribution, and we assume for this category

162 the average fate of all other categories.

Releases to different environmental reservoirs are calculated on a global scale by

164 multiplying the $\mathrm{Hg}$ consumed in each use category and decade by the corresponding distribution

165 factors. Most products are disposed of and enter the environment within the decade when they

166 were produced, and manufacturing processes generally consume and release $\mathrm{Hg}$ within a year. ${ }^{13 \text {, }}$

167 15, 16, 30, 47-50 Products in the Wiring Devices and Industrial Measuring Devices category are often

168 in use for 20-50 years before disposal. ${ }^{13-15,30,49}$ For these products we follow the methods of 
169 Jasinski et al. ${ }^{13}$ and Cain et al. ${ }^{16}$ and assume that $10 \%$ are discarded after 10 years, $40 \%$ after 30

170 years, and the remaining 50\% after 50 years. Dental amalgams generally remain in living teeth

171 for 10 to 30 years or more. We estimate excretion and exhalation releases from dental amalgam

172 to air and water during this time and track the remaining $\mathrm{Hg}$ that will be released through

173 cremation pathways or permanently stored through burial after 30 to 50 years, depending on

174 average life expectancy ${ }^{51}$ and ages of individuals receiving fillings. ${ }^{16}$

175 Recycled $\mathrm{Hg}$ is estimated separately for internal reuse of $\mathrm{Hg}$ in chemicals manufacturing 176 and large-scale mining ${ }^{30,52,53}$ and external recycling of $\mathrm{Hg}$ in products like batteries that returns

$177 \mathrm{Hg}$ to the global $\mathrm{Hg}$ supply for future use. ${ }^{53}$ External recycling did not become widespread until

178 1990. ${ }^{13}$ We do not tie our estimates of recycled Hg to global Hg supply, and instead use

179 estimated total $\mathrm{Hg}$ supply from Wilson et al. ${ }^{20}$ which includes all secondary sources for 1990 -

180 present. We assume that no $\mathrm{Hg}$ is released to the environment during the recycling process,

181 based on available data suggesting releases are negligible. ${ }^{53}$

Implications for the Biogeochemical Hg Cycle and Atmospheric Trends

183 We use the fully-coupled global biogeochemical $\mathrm{Hg}$ box model from Amos et al. ${ }^{4}$ to

184 track the fate of commercial $\mathrm{Hg}$ after it has been released to the environment. The model

185 includes seven reservoirs that represent the atmosphere, ocean (surface, subsurface, and deep),

186 and terrestrial pools (fast, slow, and armored). Fluxes between reservoirs are determined by first-

187 order rate coefficients applied to the inventory of the exporting reservoir. Atmospheric rate

188 coefficients are from Holmes et al. ${ }^{54}$ and oceanic rate coefficients are from Soerensen et al. ${ }^{55}$ and

189 Sunderland and Mason $^{56}$ (for a full list, see Table S3). Riverine rate coefficients have been

190 updated following Amos et al. ${ }^{57}$ to include the settling of particle-bound $\mathrm{Hg}$ to benthic estuarine 
191 and shelf sediments. This effectively adds a permanent sink from the terrestrial pools. Primary

192 anthropogenic and geogenic emissions are treated as external forcings.

We added a landfill reservoir to this model. Landfills can emit $\mathrm{Hg}$ into the atmosphere

194 through vent pipes, diffusion from cover soil, and from the "working face" where waste is

195 exposed and actively dumped. ${ }^{31}$ They can also release Hg into groundwater and soils through the

196 base of the landfill but this appears to be negligible. ${ }^{58}$ Data available on $\mathrm{Hg}$ emissions for

197 managed landfills in China, ${ }^{31}$ the United States, ${ }^{59}$ and Korea ${ }^{60}$ indicate low values. We find a

198 mean lifetime of 20,000 years for $\mathrm{Hg}$ in landfills by combining emissions values for each site

199 with estimated $\mathrm{Hg}$ reservoirs inferred from the waste content and disposal magnitudes. Landfills

200 as defined here can therefore effectively be viewed as a permanent sink.

201 Commercial Hg enters the biogeochemical cycle via the atmosphere, water, soil, and

202 landfills. Hg releases to soil are distributed among the three terrestrial reservoirs of the model in

203 the same manner as atmospherically deposited $\mathrm{Hg}$ in Amos et al. ${ }^{4} \mathrm{Hg}$ releases to water are

204 distributed as $90 \%$ to inland freshwater systems and $10 \%$ to estuaries based on the distribution of

205 present-day point sources. ${ }^{57,61} \mathrm{We}$ assume that $75 \%$ of the $\mathrm{Hg}$ input to inland freshwater systems

206 is sequestered permanently in sediments and $25 \%$ evades to the atmosphere, based on models for

207 a variety of lakes and rivers. ${ }^{62}$ Based on previous work, we assume that $50 \%$ of the $\mathrm{Hg}$ directly

208 released to estuaries is transported to the surface ocean, $10 \%$ evades to the atmosphere, and $40 \%$

209 is sequestered permanently in coastal sediments. ${ }^{63,64}$ In this manner, we estimate that $70 \%$ of $\mathrm{Hg}$

210 released to water is permanently sequestered, $23 \%$ enters the atmosphere, and $7 \%$ enters the

211 surface ocean.

212 We apply the box model to time-dependent simulations from $2000 \mathrm{BC}$ to 2010 following 
213 the methods described in Amos et al. ${ }^{4}$ We simulate 1850 - 2010 with anthropogenic atmospheric

214 emissions from Streets et al. ${ }^{12}$ plus the releases from commercial Hg quantified in this study. We

215 evaluate the model with three global observational constraints, following Amos et al. ${ }^{4}:$ (1) the

216 present-day atmospheric inventory (best estimate of $5000 \mathrm{Mg}$, range $4600-5600 \mathrm{Mg}$ ), (2) the

217 present-day mean upper (0 to $1500 \mathrm{~m}$ ) ocean concentration (best estimate of $1.0 \mathrm{pM}$, range 0.5 -

$2181.5 \mathrm{pM}$ ), and (3) the relative anthropogenic enrichment factor (AEF) in atmospheric deposition

219 between pre-industrial and present-day (best estimate of 3, range 2 to 5). We define our model

220 AEF as the ratio of average 1985-2000 deposition to average 1760-1880 deposition. ${ }^{65,66}$ These

221 two time intervals are empirically determined from the compilation of lake sediments described

222 in Biester et al. ${ }^{67}$ to provide a more consistent comparison between models and observations. ${ }^{65}$

\section{RESULTS AND DISCUSSION}

224 Global Commercial Hg Consumption Patterns, 1850 - 2010

225 Figure 3 shows the global commercial use of $\mathrm{Hg}$ since 1850 for all categories described

226 in Table 1, and partitioned between the developed and developing world after 1970. Prior to

227 1900, almost all mined Hg was used in silver and gold mining. In the $20^{\text {th }}$ century, Hg uses

228 diversified greatly. $\mathrm{Hg}$ use in large-scale mining declined following the end of the gold rush and

229 as extraction methods that did not require $\mathrm{Hg}$ became widespread. The 1940s peak in Figure 3 is

230 driven by chemicals production for munitions during WWII. The 1970s peak represents the

231 height of $\mathrm{Hg}$ use in consumer products like paint and batteries. Total consumption declined after

232 the 1970s when many developed countries implemented regulations on $\mathrm{Hg}$ uses and

233 environmental releases. Since 1990, the developing world has dominated global $\mathrm{Hg}$ 
234 consumption. ASGM in developing countries is presently the largest use of Hg globally, and is

235 increasing. ${ }^{22,68}$

236 Environmental Releases of Commercial $\mathrm{Hg}$

237 Figure 4 compares the historical atmospheric emissions inventory of Streets et al. ${ }^{12}$

238 (including sources from combustion, metals smelting, mining, and chlor-alkali plants) with our

239 best estimate of additional releases to air, water, soil, and landfills from commercial $\mathrm{Hg}$. Streets

240 et al. ${ }^{12}$ estimate total emissions to air of $215 \mathrm{Gg}$ since 1850 . Additional releases in our inventory

241 over the same period total $540 \mathrm{Gg}$. Of these, $230 \mathrm{Gg}$ are permanently sequestered in landfills or

242 in benthic sediments of freshwater and estuarine systems. The remaining $310 \mathrm{Gg}$ (including 110

243 Gg emitted to air) cycle between biogeochemical reservoirs and represent a larger anthropogenic

244 perturbation to the global $\mathrm{Hg}$ cycle than the $215 \mathrm{Gg}$ of Streets et al. ${ }^{12}$ Commercial Hg thus

245 represents a major, previously unquantified source of $\mathrm{Hg}$ to the global environment. The

246 temporal pattern of anthropogenic Hg releases is also affected. Whereas Streets et al. ${ }^{12}$ indicate

247 rising emissions since 1950, our estimate shows a decline in total releases from 1970 to 2000.

Figure 5 presents the historical contributions of individual commercial use categories to

249 global environmental releases to air, water, soil, and landfills. Releases to air, water, and soil all

250 show similar enhancements from late $19^{\text {th }}$-century mining. Differences are attributable to

251 changes in the fate of commercial Hg over time. Emissions to air peak in 1970, mainly due to

252 paint volatilization and incineration of batteries. Although $\mathrm{Hg}$ use in batteries increased from

2531970 to 1980 , open-air waste burning at landfills was eliminated during this period following

254 solid waste regulations. ${ }^{69,70}$ Use of explosives and weapons was a major emitter to air during

$2551900-1950$ with a peak in WWII. 
Water releases also exhibit a peak during WWII, due to laboratory uses and chemicals

257 manufacturing. The overall maximum occurs in 1960, with a steep subsequent decline following

258 implementation of chlor-alkali liquid effluent regulations in the early 1970s in North America

259 and Europe. ${ }^{71,72}$ Implementation of wastewater treatment from the 1980s onward led to even

260 greater declines in water releases, ${ }^{73}$ but contributes a small amount to soils due to application of

261 Hg-containing sludges. ${ }^{16,53}$ Similarly, chlor-alkali plants began capturing Hg in sludges in the

2621970 s, which were subsequently dumped on land or landfilled on-site. ${ }^{72}$ The 1970 peak in soil

263 releases is driven by $\mathrm{Hg}$ used in chlor-alkali plants and $\mathrm{Hg}$-containing pesticides and fertilizer

264 that were applied directly to land.

265 Implications for the Biogeochemical Hg Cycle and Atmospheric Trends

266 Figure 6 shows simulated atmospheric $\mathrm{Hg}$ from 1850-present after adding our inventory

267 of commercial $\mathrm{Hg}$ releases to the updated global biogeochemical $\mathrm{Hg}$ model, which includes

268 burial of riverine $\mathrm{Hg}$ in benthic sediments of coastal marine systems from Amos et al. ${ }^{57}$ and an

269 additional reservoir representing landfills. Our simulated present-day atmospheric reservoir is

$2705800 \mathrm{Mg}$, the mean $\mathrm{Hg}$ concentration in the upper ocean is $1.5 \mathrm{pM}$, and the AEF for atmospheric

271 deposition is 4.4. The original Amos et al. ${ }^{4}$ simulation not including commercial $\mathrm{Hg}$ yielded a

272 present-day atmosphere of $5300 \mathrm{Mg}$, but did not account for burial of riverine $\mathrm{Hg}$. Accounting

273 for burial without commercial $\mathrm{Hg}$ results in an atmosphere that is too low $(2700 \mathrm{Mg})$.

274 Conversely, including commercial $\mathrm{Hg}$ in the original Amos et al. ${ }^{4}$ simulation without burial

275 would yield a present-day atmospheric reservoir of $10,000 \mathrm{Mg}$, much higher than observed.

276 Our simulated present-day atmospheric reservoir of $5800 \mathrm{Mg}$ is still slightly higher than

277 the observational range $(4600-5600 \mathrm{Mg})$. This is due to the increase over the past decade (Figure 
278 6) driven by rising anthropogenic atmospheric emissions in the Streets et al. ${ }^{12}$ inventory

279 (primarily from coal burning in Asia) and rising releases from $\mathrm{ASGM}^{22}$ (Figures 3 and 4).

280 However, Wilson et al. ${ }^{20}$ suggest that global anthropogenic emissions have in fact remained

281 relatively constant since 2000, and AMAP/UNEP ${ }^{22}$ suggest that the ASGM increase since 2000

282 may be an artifact of improved reporting. We conducted a sensitivity simulation holding constant

283 anthropogenic atmospheric emissions and ASGM releases for the 2000-2010 period, and results

284 are shown as the dashed line in Figure 6. We obtain in that simulation an atmospheric reservoir

285 of $5000 \mathrm{Mg}$, more consistent with observations, and unchanged upper ocean concentration of 1.5

$286 \mathrm{pM}$ and AEF of 4.4. Alternatively, the atmospheric reservoir could be reduced within the range

287 of observational constraints if the efficacy of $\mathrm{Hg}$ re-emission from soils were decreased, a

288 change supported by recent observational evidence. ${ }^{74,75}$

Inclusion of commercial $\mathrm{Hg}$ releases in our global biogeochemical model improves

290 model consistency with archival records of atmospheric deposition. Lake sediments and

291 ombrotrophic peat bogs generally indicate a gradual rise over the industrial era with a peak in the

2921970 s. ${ }^{33-36}$ Figure 6 indicates a 1970s peak in simulated atmospheric $\mathrm{Hg}$ and a muted $19^{\text {th }}$

293 century mining signal. Without the inclusion of commercial $\mathrm{Hg}$, model deposition increases from

2941970 to present and there is a prominent $19^{\text {th }}$ century peak. ${ }^{4}$ Our inventory also helps to explain

295 the observed 1990-present declines in atmospheric Hg over North America and Europe. ${ }^{37,38}$

Our work shows that environmental releases of commercial $\mathrm{Hg}$ to air, water, and soil

297 over the industrial period have represented a major and previously unquantified perturbation to

$298 \mathrm{Hg}$ in the global environment. The legacy of this source in oceanic and terrestrial reservoirs has

299 important implications for policy. Future work should examine the geographical distribution of

300 commercial $\mathrm{Hg}$ releases and its impact on regional-scale environmental $\mathrm{Hg}$ loadings and 
301 atmospheric trends. Better understanding of the role of soils for long-term storage of

302 anthropogenic $\mathrm{Hg}$ is also critically needed.

303 ACKNOWLEDGEMENTS. We acknowledge financial support for this work from Harvard

304 School of Engineering and Applied Sciences TomKat Fund and the Atmospheric Chemistry

305 Program of the National Science Foundation. H.M.H. acknowledges support from NSF GRFP.

306 SUPPORTING INFORMATION. Additional information on data sources used to estimate

307 distribution factors (Table S1), distribution factors used in this study (Table S2), and model rate

308 coefficients (Table S3). This material is available free of charge via the Internet at

309 http://pubs.acs.org.

\section{REFERENCES}

311 1. Mahaffey, K. R.; Sunderland, E. M.; Chan, H. M.; Choi, A. L.; Grandjean, P.; Marien,

312 K.; Oken, E.; Sakamoto, M.; Schoeny, R.; Weihe, P.; Yan, C. H.; Yasutake, A. Balancing the

313 benefits of n-3 polyunsaturated fatty acids and the risks of methylmercury exposure from fish

314 consumption. Nutrition Reviews 2011, 69, (9), 493-508.

315 2. Karagas, M. R.; Choi, A. L.; Oken, E.; Horvat, M.; Schoeny, R.; Kamai, E.; Cowell, W.;

316 Grandjean, P.; Korrick, S. Evidence on the Human Health Effects of Low-Level Methylmercury

317 Exposure. Environmental Health Perspectives 2012, 120, (6), 799-806.

318 3. Nriagu, J. O. Production and uses of mercury. In The biogeochemistry of mercury in the

319 environment; Nriagu, J. O. Ed.; Elsevier/North-Holland Biomedial Press: Amsterdam, the

320 Netherlands, 1979; pp 23-40. 
321 4. Amos, H. M.; Jacob, D. J.; Streets, D. G.; Sunderland, E. M. Legacy impacts of all-time 322 anthropogenic emissions on the global mercury cycle. Global Biogeochemical Cycles 2013, 27, 323 (2), 410-421.

324 5. Fitzgerald, W. F.; Engstrom, D. R.; Mason, R. P.; Nater, E. A. The case for atmospheric 325 mercury contamination in remote areas. Environmental Science \& Technology 1998, 32, (1), 1-7.

326 6. Serrano, O.; Martinez-Cortizas, A.; Mateo, M. A.; Biester, H.; Bindler, R. Millennial 327 scale impact on the marine biogeochemical cycle of mercury from early mining on the Iberian 328 Peninsula. Global Biogeochemical Cycles 2013, 27, (1), 21-30.

329 7. Mason, R. P.; Fitzgerald, W. F.; Morel, F. M. M. The Biogeochemical Cycling of 330 Elemental Mercury - Anthropogenic Influences. Geochim. Cosmochim. Acta 1994, 58, (15), $331 \quad 3191-3198$.

332 8. Selin, N. E.; Jacob, D. J.; Yantosca, R. M.; Strode, S.; Jaegle, L.; Sunderland, E. M. 333 Global 3-D land-ocean-atmosphere model for mercury: Present-day versus preindustrial cycles 334 and anthropogenic enrichment factors for deposition. Global Biogeochemical Cycles 2008, 22, 335 (2).

336 9. Slemr, F.; Schuster, G.; Seiler, W. Distribution, Speciation, and Budget of Atmospheric 337 Mercury. J Atmos Chem 1985, 3, (4), 407-434.

338 10. Andren, M. O.; Nriagu, J. O. The global cycle of mercury. In The biogeochemistry of 339 mercury in the environment; Nriagu, J. O. Ed.; 1979; pp 1-15.

340 11. Minamata Convention on Mercury: Text and Annexes; United Nations Environment 341 Programme: Nairobi, Kenya, 2013. 
342 12. Streets, D. G.; Devane, M. K.; Lu, Z.; Bond, T. C.; Sunderland, E. M.; Jacob, D. J. All-

343 Time Releases of Mercury to the Atmosphere from Human Activities. Environmental Science \&

344 Technology 2011, 45, (24), 10485-10491.

345 13. Jasinski, S. M. The materials flow of mercury in the United States; Bureau of Mines

346 Information Circular IC 9412; U.S. Department of the Interior: Washington, DC, 1994.

347 14. Substance Flow Analysis of Mercury in Products; Barr Engineering: Minneapolis, MN, 348 August 15, 2001.

349 15. Assessment of Mercury Releases from the Russian Federation; Arctic Council Action 350 Plan to Eliminate Pollution of the Arctic (ACAP), Russian Federal Service for Environmental, 351 Technological and Atomic Supervision \& Danish Environmental Protection Agency:

352 Copenhagen, Denmark, 2005.

353 16. Cain, A.; Disch, S.; Twaroski, C.; Reindl, J.; Case, C. R. Substance flow analysis of 354 mercury intentionally used in products in the United States. Journal of Industrial Ecology 2007, $35511,(3), 61-75$.

356 17. Kindbom, K.; Munthe, J. Product-related emissions of Mercury to Air in the European 357 Union; IVL Swedish Environmental Research Institute Ltd. : Göteborg, Sweden, 2007.

358 18. Pacyna, E. G.; Pacyna, J. M.; Sundseth, K.; Munthe, J.; Kindbom, K.; Wilson, S.;

359 Steenhuisen, F.; Maxson, P. Global emission of mercury to the atmosphere from anthropogenic 360 sources in 2005 and projections to 2020. Atmospheric Environment 2010, 44, (20), 2487-2499.

361 19. Pirrone, N.; Cinnirella, S.; Feng, X.; Finkelman, R. B.; Friedli, H. R.; Leaner, J.; Mason, 362 R.; Mukherjee, A. B.; Stracher, G. B.; Streets, D. G.; Telmer, K. Global mercury emissions to the 
363 atmosphere from anthropogenic and natural sources. Atmospheric Chemistry and Physics 2010, $36410,(13), 5951-5964$.

365 20. Wilson, S.; Munthe, J.; Sundseth, K.; Kindbom, K.; Maxson, P.; Pacyna, J. M.;

366 Steenhuisen, F. Updating Historical Global Inventories of Anthropogenic Mercury Emissions to 367 Air; Arctic Monitoring and Assessment Program (AMAP): Oslo, Norway, 2010.

368 21. Sundseth, K.; Pacyna, J.; Pacyna, E.; Panasiuk, D. Substance Flow Analysis of Mercury 369 Affecting Water Quality in the European Union. Water, Air, \& Soil Pollution 2011, 1-14.

370 22. Technical Background Report for the Global Mercury Assessment 2013; Arctic

371 Monitoring and Assessment Programme (AMAP), Oslo, Norway/UNEP Chemicals Branch, 372 Geneva, Switzerland: 2013.

373 23. Chakraborty, L. B.; Qureshi, A.; Vadenbo, C.; Hellweg, S. Anthropogenic Mercury 374 Flows in India and Impacts of Emission Controls. Environmental Science \& Technology 2013, $37547,(15), 8105-8113$.

376 24. Taylor, C. G. The loss of mercury from fungicidal paints. Journal of Applied Chemistry $377 \mathbf{1 9 6 5 ,} 232-236$.

378 25. D'Itri, P. A.; D'Itri, F. M. Mercury Contamination: A Human Tragedy; John Wiley \& 379 Sons: New York, 1977.

380 26. Rudd, J. W. M.; Turner, M. A.; Furutani, A.; Swick, A. L.; Townsend, B. E. The English 381 Wabigoon River System .1. A Synthesis of Recent Research with a View Towards Mercury 382 Amelioration. Can J Fish Aquat Sci 1983, 40, (12), 2206-2217. 
383 27. Gill, G. A.; Bloom, N. S.; Cappellino, S.; Driscoll, C. T.; Dobbs, C.; McShea, L.; Mason, 384 R.; Rudd, J. W. M. Sediment-water fluxes of mercury in Lavaca Bay, Texas. Environmental 385 Science \& Technology 1999, 33, (5), 663-669.

386 28. Kocman, D.; Horvat, M.; Pirrone, N.; Cinnirella, S. Contribution of contaminated sites to 387 the global mercury budget. Environmental Research 2013, 125, 160-170.

388 29. Rissanen, K.; Miettinen, J. K. Use of mercury compounds in agriculture and its 389 implications. In Mercury Contamination in Man and his Environment: a joint undertaking by the 390 International Labor Organisation, Food and Agriculture Organization of the United Nations, 391 The World Health Organization and the International Atomic Energy Agency; International 392 Atomic Energy Agency: Vienna, Austria, 1972.

393 30. Characterization of Products Containing Mercury in Muncipal Solid Waste in the United 394 States, 1970 to 2000; U.S. Environmental Protection Agency, Office of Solid Waste, Municipal 395 and Industrial Solid Waste Division: Washington, DC, 1992.

396 31. Li, Z. G.; Feng, X.; Li, P.; Liang, L.; Tang, S. L.; Wang, S. F.; Fu, X. W.; Qiu, G. L.; 397 Shang, L. H. Emissions of air-borne mercury from five municipal solid waste landfills in 398 Guiyang and Wuhan, China. Atmospheric Chemistry and Physics 2010, 10, (7), 3353-3364.

399 32. Brooks, W. E.; Matos, G. R. Mercury recycling in the United States in 2000. In Flow 400 studies for recycling metal commodities in the United States: U.S. Geological Survey Circular 401 1196-U, Sibley, S. F. comp. Ed.; 2005; p 21. 
402 33. Kamman, N. C.; Engstrom, D. R. Historical and present fluxes of mercury to Vermont 403 and New Hampshire lakes inferred from $\mathrm{Pb}-210$ dated sediment cores. Atmospheric Environment 404 2002, 36, (10), 1599-1609.

405 34. Engstrom, D. R.; Balogh, S. J.; Swain, E. B. History of mercury inputs to Minnesota 406 lakes: Influences of watershed disturbance and localized atmospheric deposition. Limnol 407 Oceanogr 2007, 52, (6), 2467-2483.

408 35. Fain, X.; Ferrari, C. P.; Dommergue, A.; Albert, M. R.; Battle, M.; Severinghaus, J.; 409 Arnaud, L.; Barnola, J. M.; Cairns, W.; Barbante, C.; Boutron, C. Polar firn air reveals large410 scale impact of anthropogenic mercury emissions during the 1970s. Proceedings of the National 411 Academy of Sciences of the United States of America 2009, 106, (38), 16114-16119.

412 36. Allan, M.; Le Roux, G.; Sonke, J. E.; Piotrowska, N.; Streel, M.; Fagel, N.

413 Reconstructing historical atmospheric mercury deposition in Western Europe using: Misten peat 414 bog cores, Belgium. Science of the Total Environment 2013, 442, 290-301.

$415 \quad 37 . \quad$ Slemr, F.; Brunke, E. G.; Ebinghaus, R.; Kuss, J. Worldwide trend of atmospheric 416 mercury since 1995. Atmospheric Chemistry and Physics 2011, 11, (10), 4779-4787.

417 38. Soerensen, A. L.; Jacob, D. J.; Streets, D. G.; Witt, M. L. I.; Ebinghaus, R.; Mason, R. P.; 418 Andersson, M.; Sunderland, E. M. Multi-decadal decline of mercury in the North Atlantic 419 atmosphere explained by changing subsurface seawater concentrations. Geophysical Research $420 \quad$ Letters 2012, 39. 
421 39. Hylander, L. D.; Meili, M. 500 years of mercury production: global annual inventory by 422 region until 2000 and associated emissions. Science of the Total Environment 2003, 304, (1-3), $423 \quad 13-27$.

424 40. Mercury statistics. In Historical statistics for mineral and material commodities in the 425 United States: U.S. Geological Survey Data Series 140, Kelly, T. D.; Matos, G. R. Comps.; 426 USGS: 2012, accessed September 25, 2013, at http://minerals.usgs.gov/ds/2005/140/.

427 41. Maxson, P. Mercury flows in Europe and the world: the impact of decommissioned chlor428 alkali plants; Concorde East/West Sprl for the European Commission Environment Directorate429 General Brussels, Belgium, February, 2004.

430 42. Mineral Resources of the United States. U.S. Geological Survey/Bureau of Mines, US 431 Department of the Interior, Government Printing Office: Washington, D.C. 1882 - 1929.

432 43. Minerals Yearbook. US Bureau of Mines, US Department of the Interior, Government 433 Printing Office: Washington, D.C. USA, 1941 - 1968.

434 44. GDP and its breakdown at constant 2005 prices in US dollars - All countries and 435 regions/subregions (totals) for all years. In National Accounts Main Aggregates Database, 436 United Nations Statistics Division: 2012.

437 45. Metal statistics. American Metal Mart: New York, 1960 - 1995.

438 46. Arenholt-Bindslev, D. Environmental aspects of dental filling materials. Eur J Oral Sci 439 1998, 106, (2), 713-720. 
440 47. Mercury Study Report to Congress Volume II: An Inventory of Anthropogenic Mercury

441 Emissions in the United States; Office of Air Quality Planning \& Standards and Office of

442 Research and Development, U.S. Environmental Protection Agency: December, 1997.

443 48. Floyd, P.; Zarogiannis, P.; Crane, M.; Tarkowski, S.; Bencko, V. Risks to health and the

444 environment related to the use of mercury products; Risk \& Policy Analysts for the European

445 Commission, DG Enterprise: Norfolk, UK, 2002.

446 49. Hagreen, L. A.; Lourie, B. A. Canadian mercury inventories: the missing pieces.

447 Environmental Research 2004, 95, (3), 272-281.

448 50. Report on the major mercury-containing products and processes, their substitutes and

449 experience in switching to mercury-free products and processes;

450 UNEP(DTIE)/Hg/OEWG.2/7/Add.1; United Nations Environment Programme (UNEP): Nairobi, 451 Kenya, 2008.

452 51. World Population Prospects: The 2010 Revision, Volume I: Comprehensive Tables;

453 ST/ESA/SER.A/313; United Nations Department of Economic and Social Affairs Population

454 Division: New York, 2011.

455 52. NRDC submission to UNEP in response to March 2006 request for information on 456 mercury supply, demand, and trade; National Resources Defense Council (NRDC): Washington, 457 DC, May, 2006.

458 53. Toolkit for Identification and Quantification of Mercury Sources, Reference Report and 459 Guidline for Inventory Level 2, Version 1.2, April 2013; UNEP Chemicals Branch: Geneva, 460 Switzerland, 2013. 
461 54. Holmes, C. D.; Jacob, D. J.; Corbitt, E. S.; Mao, J.; Yang, X.; Talbot, R.; Slemr, F.

462 Global atmospheric model for mercury including oxidation by bromine atoms. Atmospheric

463 Chemistry and Physics 2010, 10, (24), 12037-12057.

$464 \quad 55 . \quad$ Soerensen, A. L.; Sunderland, E. M.; Holmes, C. D.; Jacob, D. J.; Yantosca, R. M.; Skov, 465 H.; Christensen, J. H.; Strode, S. A.; Mason, R. P. An Improved Global Model for Air-Sea 466 Exchange of Mercury: High Concentrations over the North Atlantic. Environmental Science \& 467 Technology 2010, 44, (22), 8574-8580.

468 56. Sunderland, E. M.; Mason, R. P. Human impacts on open ocean mercury concentrations. 469 Global Biogeochemical Cycles 2007, 21, (4).

470 57. Amos, H. M.; Jacob, D. J.; Sunderland, E.; Horowitz, H. M.; et al. Impacts of recent 471 changes in mercury discharges from rivers on the marine environment. To be submitted for 472 publication.

473 58. Li, Z; Feng, X. Balance of Mercury in a Modern Municipal Solid Waste Landfill in 474 China. In Air \& Waste Management Association International Specialty Conference, Xi'an, 475 China, 2010.

476 59. Lindberg, S. E.; Southworth, G. R.; Bogle, M. A.; Blasing, T. J.; Owens, J.; Roy, K.; 477 Zhang, H.; Kuiken, T.; Price, J.; Reinhart, D.; Sfeir, H. Airborne emissions of mercury from 478 municipal solid waste. I: New measurements from six operating landfills in Florida. Journal of 479 the Air \& Waste Management Association 2005, 55, (7), 859-869.

$480 \quad$ 60. Kim, S.; Karl, T.; Guenther, A.; Tyndall, G.; Orlando, J.; Harley, P.; Rasmussen, R.; 481 Apel, E. Emissions and ambient distributions of Biogenic Volatile Organic Compounds (BVOC) 
482 in a ponderosa pine ecosystem: interpretation of PTR-MS mass spectra. Atmospheric Chemistry 483 and Physics 2010, 10, (4), 1759-1771.

484 61. Kocman, D.; Horvat, M.; et al. A Global Inventory of Present-Day Mercury Releases to 485 Aquatic Environments. To be submitted for publication.

486 62. Knightes, C. D.; Sunderland, E. M.; Barber, M. C.; Johnston, J. M.; Ambrose, R. B. 487 Application of Ecosystem-Scale Fate and Bioaccumulation Models to Predict Fish Mercury 488 Response Times to Changes in Atmospheric Deposition. Environ Toxicol Chem 2009, 28, (4), $489 \quad 881-893$.

490 63. Mason, R. P.; Lawson, N. M.; Lawrence, A. L.; Leaner, J. J.; Lee, J. G.; Sheu, G. R. 491 Mercury in the Chesapeake Bay. Mar Chem 1999, 65, (1-2), 77-96.

492 64. Sunderland, E. M.; Dalziel, J.; Heyes, A.; Branfireun, B. A.; Krabbenhoft, D. P.; Gobas, 493 F. A. P. C. Response of a Macrotidal Estuary to Changes in Anthropogenic Mercury Loading 494 between 1850 and 2000. Environmental Science \& Technology 2010, 44, (5), 1698-1704.

495 65. Sonke, J. E. GET-Observatoire Midi-Pyrénées, CNRS, Université de Toulouse III, 496 Toulouse, France. Personal communication, 2014.

497 66. Amos, H. M.; Sunderland, E.; Corbitt, E. S.; Hedgecock, I.; Kocman, D.; Krabbenhoft, 498 D.; Lamborg, C. H.; Obrist, D.; Pirrone, N.; Sonke, J. E.; Witt, M. L. I.; Horowitz, H. M. 499 Defining natural and anthropogenic mercury impacts. To be submitted for publication.

500 67. Biester, H.; Bindler, R.; Martinez-Cortizas, A.; Engstrom, D. R. Modeling the past 501 atmospheric deposition of mercury using natural archives. Environmental Science \& Technology $502 \quad 2007,41,(14), 4851-4860$. 
503 68. Telmer, K. M.; Veiga, M. M. World Emissions of Mercury from Artisanal and Small

504 Scale Gold Mining. Mercury Fate and Transport in the Global Atmosphere 2009, 131-172.

505 69. Municipal Solid Waste in the United States: 2001 Facts and Figures; EPA530-R-03-011;

506 U.S. Environmental Protection Agency, Office of Solid Waste and Emergency Response:

507 Washington, DC, 2003.

508 70. Modern Landfills: A Far Cry from the Past; National Solid Wastes Management

509 Association: Washington, DC, 2008.

510 71. Flewelling, F. J. In Loss of mercury to the environment from chlor-alkali plants, Special 511 symposium on mercury in man's environment, Ottawa, Canada, February 15-16, 1971; Watkin, 512 J. E., Ed.; National Research Council of Canada: Ottawa, Canada, 1971.

513 72. Trip, L.; Thorleifson, M. The Canadian Mercury Cell Chlor-Alkali industry: Mercury

514 Emissions and Status of Facilities 1935 - 1996; Environment Canada, Transboundary Air Issues

515 Branch: Quebec, Canada, April, 1998.

516 73. Materials balance and technology assessment of mercury and its compounds on national

517 and regional bases; EPA 560/3-75-007; U.S. Environmental Protection Agency Office of Toxic

518 Substances: Washington, D.C. October, 1975.

519 74. Obrist, D.; Pokharel, A. K.; Moore, C. Vertical Profile Measurements of Soil Air Suggest

520 Immobilization of Gaseous Elemental Mercury in Mineral Soil. Environmental Science \&

521 Technology 2014, 48, (4), 2242-2252.

522 75. Krabbenhoft, D. Understanding the Propagation of Atmospheric Mercury through 523 Terrestrial Landscapes: After Twenty Five Years of Research does the Story Make Sense? 
524 Presented at 11th International Conference on Mercury as a Global Pollutant, Edinburgh, 525 Scotland, July 2013. 


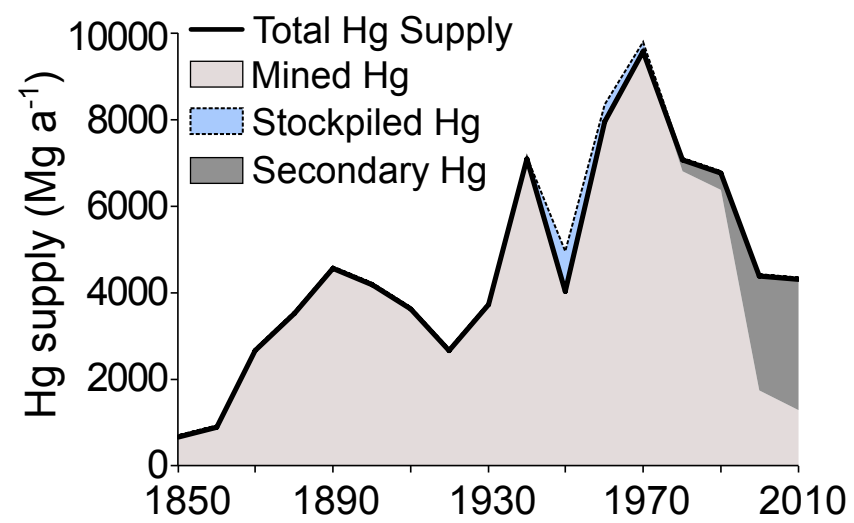

527 Figure 1. Historical global supply of $\mathbf{H g}$ for commercial uses. This supply includes primary 528 mined Hg (1850 - 2008 data from Streets et al. $\left.{ }^{10}\right)$, minus the amount stockpiled by the United 529 States between 1945 and 1970, and augmented by secondary Hg including recycled, recovered as 530 a byproduct, and released from stockpiles after 1980. 


\author{
Table 1. Intentional uses of $\mathrm{Hg}$ in products and processes. \\ Category name \\ Chlor-Alkali Plants \\ Silver and Large-scale Gold Mining \\ Artisanal and Small-Scale Gold \\ Mining (ASGM) \\ Vinyl Chloride Monomer (VCM) \\ and Other Chemical \\ Paint \\ Lamps \\ Batteries \\ Wiring Devices and Industrial \\ Measuring Devices \\ Medical Devices \\ Pharmaceuticals and Personal Care \\ Products \\ Dental amalgam \\ Dyes/Vermilion \\ Pesticides and Fertilizer \\ Explosives/Weapons \\ Other \\ Description \\ Electrochemical production of caustic soda and chlorine with $\mathrm{Hg}$ \\ cathode \\ Extraction from ore by $\mathrm{Hg}$ amalgamation \\ $\mathrm{Hg}$ amalgamation by individual miners \\ Production of chemicals with $\mathrm{Hg}$ catalysts, felt hat manufacturing, \\ and laboratory uses \\ $\mathrm{Hg}$ fungicide in marine anti-fouling paint, interior and exterior \\ latex paint \\ All types of Hg-containing lightbulbs (fluorescent, high intensity \\ discharge, etc.) \\ Button cells and cylinders using $\mathrm{Hg}$ as cathode or to prevent \\ corrosion \\ Switches and relays, thermostats, barometers, manometers \\ Thermometers and sphygmomanometers (blood pressure meters) \\ Vaccines and medicines, soaps, cosmetics \\ Cavity fillings with $\mathrm{Hg} /$ silver/tin/copper amalgam \\ Pigments containing Hg compounds \\ Fungicides used in agriculture and pulp and paper \\ Munitions, blasting caps, fireworks \\ Ritual, cultural, and miscellaneous uses
}




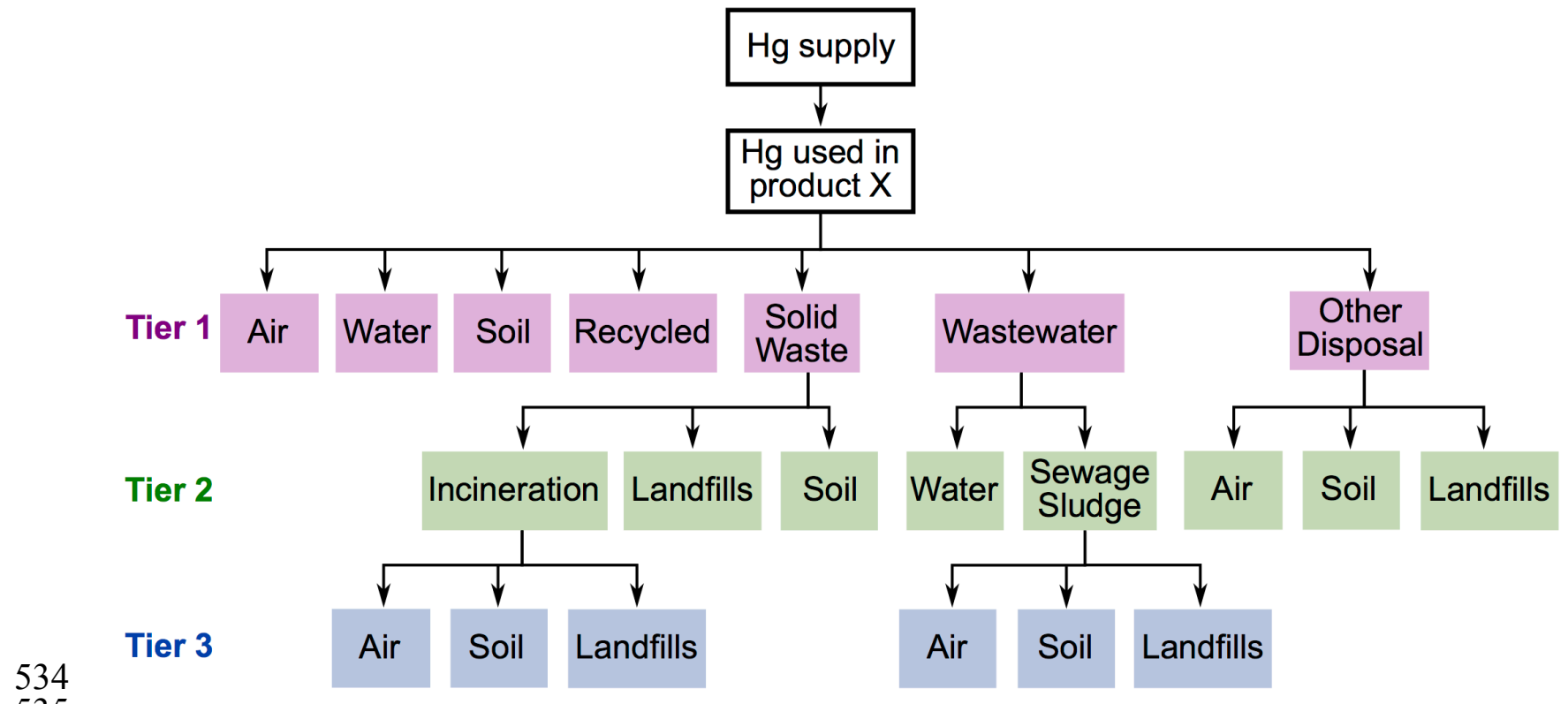

Figure 2. Generic substance flow analysis diagram for commercial $\mathrm{Hg}$. Each arrow is a

537 distribution factor quantified in this work (Table S3). This diagram applies to all intentional use 538 categories with the exception of dental amalgam, which has additional pathways (see Methods).

539 "Other disposal" refers to medical waste incineration (for Medical Devices and Dental use

540 categories) and iron and steel recycling (for Wiring Devices and Industrial Measuring Devices 541 use category). 


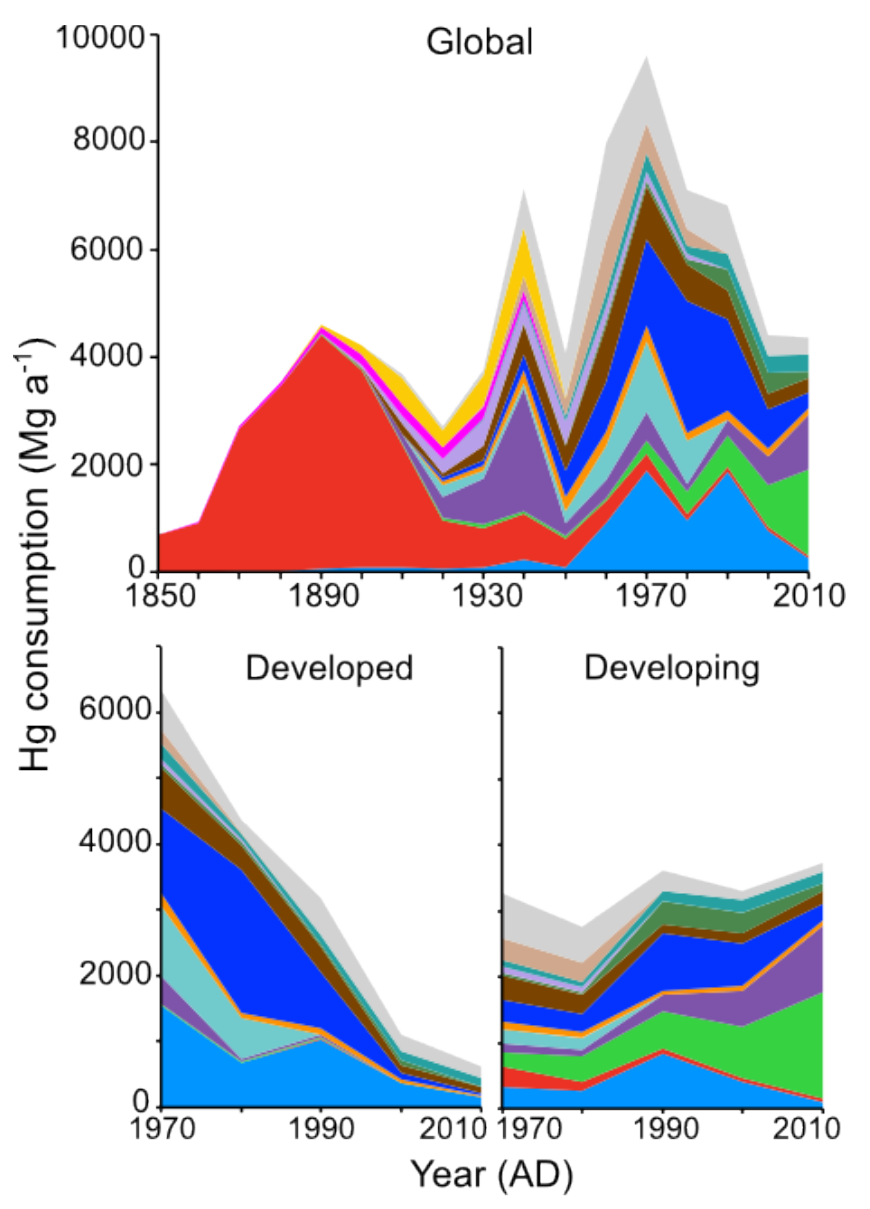

\begin{tabular}{|ll|}
\hline Other & Batteries \\
Explosives/Weapons & Lamps \\
Pesticides/Fertilizer & Paint \\
Dyes/Vermilion & VCM/Other Chemical \\
Dental & ASGM \\
Pharmaceuticals/PCPs & Chlor-alkali \\
Medical Devices & \\
Wiring/Measuring Devices \\
Silver/Large-scale gold mining
\end{tabular}

Figure 3. Global historical Hg consumption in commercial products. Consumption is 546 partitioned for each decade between the different use categories of Table 1, and further partitioned between developed countries and developing countries after 1970. 


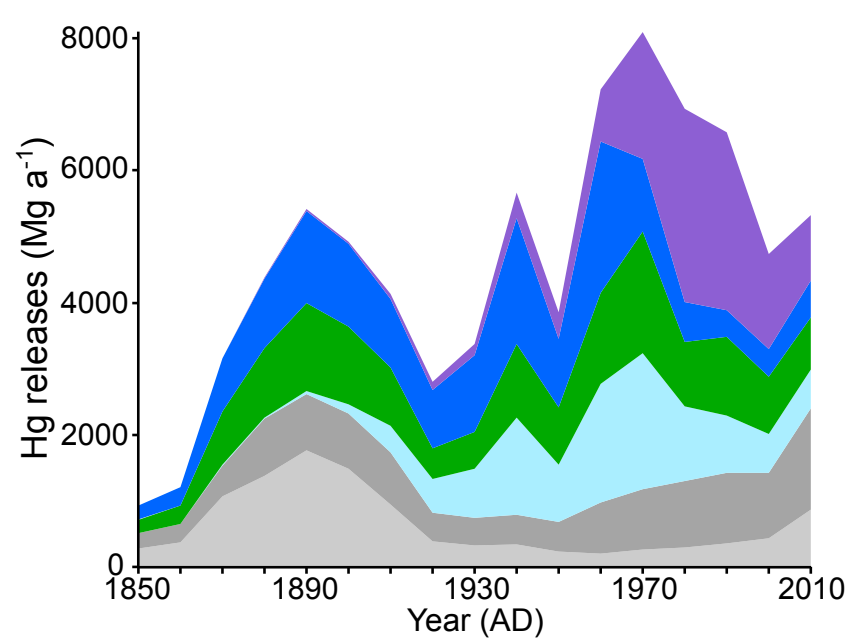
includes atmospheric releases from combustion, smelting, mining, and chlor-alkali plants. Additional air, soil, water, and landfill releases shown are associated with commercial $\mathrm{Hg}$ products as quantified in this work. 

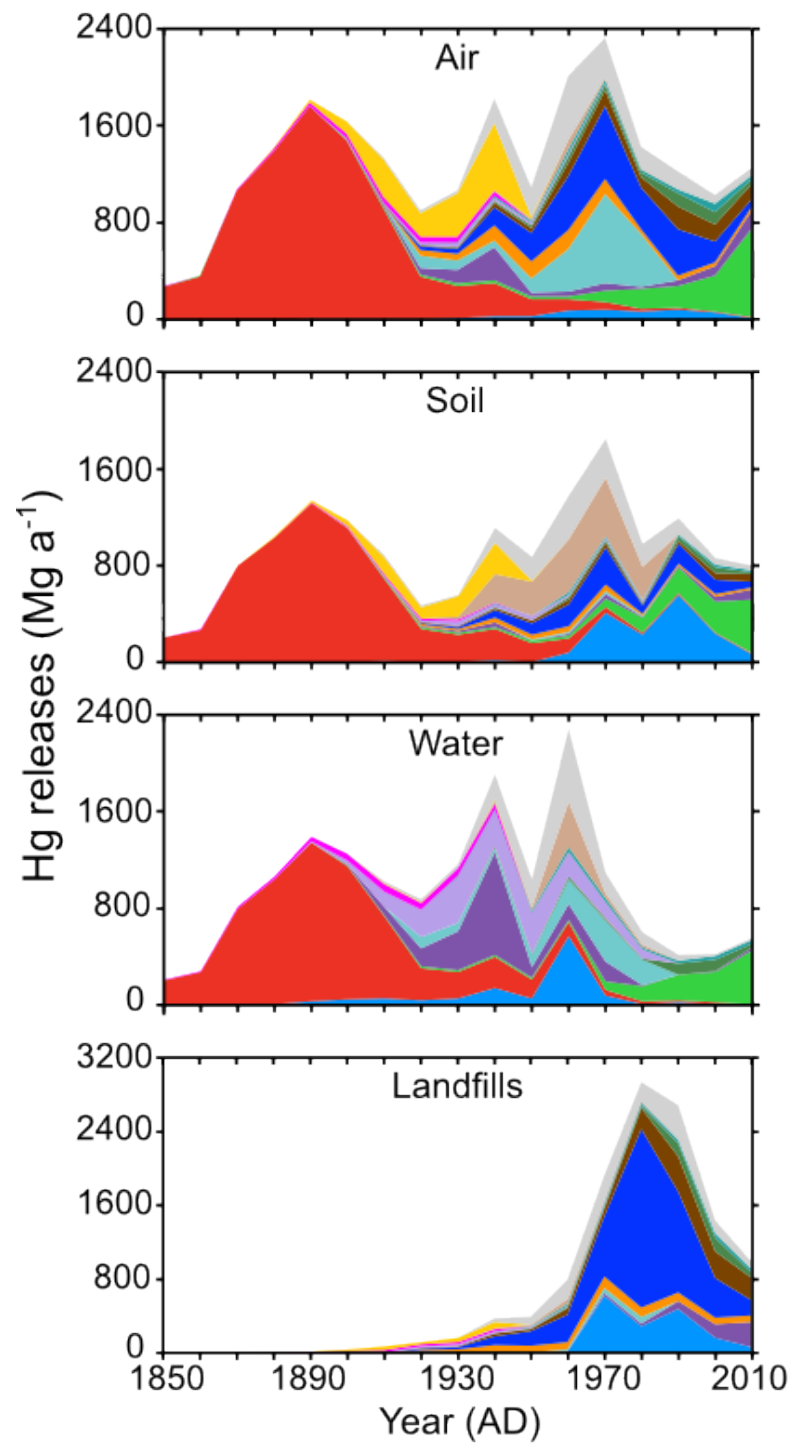

\begin{tabular}{|l|l|}
\hline Other & Batteries \\
Explosives/Weapons & Lamps \\
Pesticides/Fertilizer & Paint \\
$\square$ Dyes/Vermilion & VCM/Other Chemical \\
Dental & ASGM \\
Pharmaceuticals/PCPs & Chlor-alkali \\
Medical Devices & \\
Wiring/Measuring Devices \\
Silver/Large-scale gold mining
\end{tabular}

553 Figure 5. Global historical releases of commercial $\mathrm{Hg}$ to environmental reservoirs by use 554 category. 


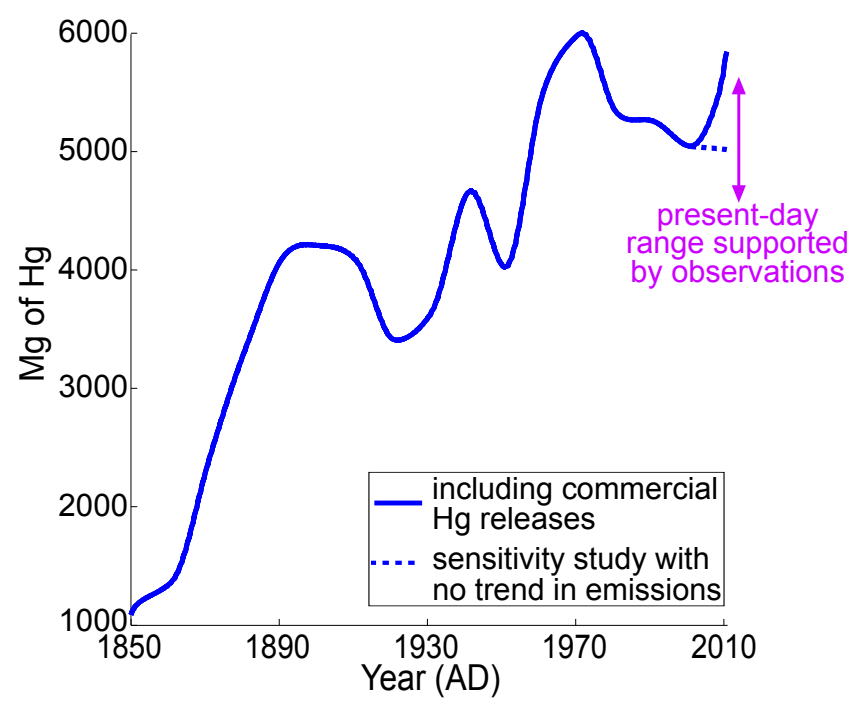

Figure 6. Trend in simulated atmospheric Hg mass from 1850 to 2010. Results shown using 557 the updated biogeochemical model described in the text, including additional commercial $\mathrm{Hg}$ 558 releases (blue) and a sensitivity simulation with ASGM releases and Streets et al. ${ }^{10}$ 559 anthropogenic atmospheric emissions held constant from 2000-2010 (dotted blue line). 